\title{
Sistem Informasi Sumber Daya Manusia (Sdm) Di Konfeksi Oidokids Bandung
}

\author{
Sri Widaningsih ${ }^{1}$, Agus Suheri ${ }^{2}$, Elly Nurullatipah ${ }^{3}$ \\ 1,2,3 Jurusan Teknik Informatika \\ Fakultas Teknik Universitas Suryakancana \\ sriwida@unsur.ac.id, agussuheri@unsur.ac.id,ellynl3399@gmail.com
}

\begin{abstract}
Management of human resources in a company is one of the most important factors so that company activities can run well. Oidokids clothing factory that produces children's Muslim clothing brands. Currently, the management of employees at the Oidokids has not been managed properly because it is still carried out manually, only using records without using a computerized system. There are several weaknesses of the current system, such as data that is not archived properly so that it is easily lost and errors in calculating attendance and payroll. Therefore we need a human resource information system that can manage employee data ranging from recruitment, training, attendance and payroll. Research method uses a waterfall software engineering form Pressman. In this study, a human resource information system was created using the PHP programming language. To model the system to be built using a unified modeling language (UML) which uses use case diagram, swimlane diagrams, class diagrams and sequence diagrams as analytical tools before designing and building the system. The system built aims to provide convenience in managing employee data at the Oidokids as well as making it easier for admins to perform employee attendance and payroll.
\end{abstract}

Keywords: information system, human resource, UML, clothing factory, waterfall

\begin{abstract}
Abstrak
Pengelolaan sumber daya manusia di suatu perusahaan merupakan salah satu faktor yang sangat penting agar kegiatan perusahaan dapat berjalan dengan baik. Konfeksi Oidokids merupakan konfeksi yang menghasilkan brand baju muslim anak. Saat ini pengelolaan karyawan di konfeksi Oidokids belum terkelola dengan baik karena masih dijalankan dengan cara manual hanya menggunakan pencatatan saja tanpa menggunakan sistem secara terkomputerisasi. Terdapat beberapa kelemahan dari sistem yang berjalan saat ini, seperti data yang tidak terarsipkan dengan baik sehingga mudah hilang, maupun kesalahan perhitungan absensi dan penggajian. Oleh karena itu dibutuhkan suatu sistem informasi sumber daya manusia yang dapat mengelola data karyawaan mulai dari perekrutan, pelatihan, absensi serta penggajian. Metode penelitian menggunakan model rekayasa perangkat lunak waterfall dari Pressman. Penelitian ini membuat sistem informasi sumber daya manusia dengan menggunakan bahasa pemrograman PHP. Untuk memodelkan sistem yang akan dibangun digunakan unified modeling language (UML) yang terdiri dari use case, swimlane diagram, class diagram dan sequence diagram. UML merupakan alat analisis sebelum merancang dan membangun sistem. Sistem yang akan dibangun bertujuan dapat memberikan kemudahan dalam mengelola data karyawan di konfeksi Oidokids serta mempermudah admin dalam melakukan absensi dan penggajian karyawan.
\end{abstract}

Kata kunci: sistem informasi, sumber daya manusia, UML, konfeksi, waterfall

\section{PENDAHULUAN}

Dalam suatu perusahaan terdapat faktor-faktor yang menunjang kegiatan perusahaan seperti manusia, mesin, peralatan, modal, dan bahan baku. Dari beberapa faktor tersebut, manusia merupakan faktor yang terpenting karena manusia adalah modal utama dari suatu perusahaan untuk mengelola faktor-faktor lainnya untuk digunakan dalam mencapai tujuan perusahaan. Manusia merupakan mahluk ciptaan Tuhan yang paling sempurna karena diberi akal, perasaan, dan pikiran. Manusia juga merupakan mahluk sosial yang dapat melakukan kerjasama dengan pihak lain. Sumber daya manusia adalah (1) manusia yang bekerja di lingkungan suatu organisasi (personil, tenaga kerja, pegawai atau karyawan, (2) potensi manusiawi sebagai penggerak organisasi dalam mewujudkan eksistensinya , (3) potensi yang merupakan asset dan berfungsi sebagai modal (non material) di dalam organisasi bisnis yang dapat diwujudkan menjadi potensi nyata secara fisik dan non fisik dalam eksistensi organisasi [1][2]. Di suatu perusahaan, biasanya terdapat bagian yang mengelola sumber daya manusia yaitu bagian personalia atau human resource development (HRD). Manajemen sumber daya manusia (MSDM) merupakan proses memperoleh, melatih, menilai dan memberikan kompensasi kepada karyawan, memperhatikan hubungan kerja , kesehatan, keamanan dan masalah keadilan [3]. MSDM adalah sistem pengelolaan sumberdaya manusia yang bersifat formal dan memperhatikan aspek efektif dan efisien 
dalam organisasi untuk mencapai tujuan bersama organisasi [4].

Teknologi informasi sudah menjadi suatu penentu tercapainya sasaran bisnis suatu perusahaan. Salah satu strategi yang digunakan yaitu pemanfaatan teknologi informasi untuk mengelola sumber daya perusahaan atau organisasi. Transparansi informasi dari setiap fungsi perusahaan dibutuhkan untuk mencapai tujuan perusahaan secara keseluruhan. Pemanfaatan sistem informasi telah dimanfaatkan secara luas di berbagai bidang, salah satunya adalah bidang manajemen sumber daya manusia yaitu dengan suatu sistem informasi.

Sistem informasi melibatkan berbagai teknologi informasi seperti komputer, perangkat lunak, basis data, sistem komunikasi, internet, perangkat seluler, dan banyak lagi, untuk melakukan tugas tertentu, berinteraksi dengan, dan menginformasikan kepada berbagai pelaku dalam konteks organisasi atau sosial yang berbeda [5]. Salah satu fungsi sistem informasi yaitu meningkatkan aksesabilitas data yang tersaji secara tepat waktu dan akurat bagi para pemakai [6].

Sistem informasi sumber daya manusia menyediakan sejumlah besar informasi tentang sumber daya manusia dalam organisasi kepada pengguna untuk mengambil keputusan rasional yang berkaitan dengan sumber daya manusia. Sistem informasi ini membantu untuk melakukan semua bidang fungsional manajemen sumber daya manusia dengan efisiensi biaya [7]. Fungsi-fungsi manajemen sumber daya manusia seperti perekrutan, pelatihan, absensi, penggajian dan manajemen data diolah dengan cara terkomputerisasi. Beberapa manfaat dari sistem informasi ini yaitu meningkatkan efisiensi dilihat dari waktu dan kepuasan manajerial [8] Selain itu pengelolaan data dapat dilakukan dengan lebih baik karena dapat menyimpan data di dalam database dalam jumlah besar. Semua informasi mengenai karyawan dapat dilacak dan diperbaharui dengan cepat. Dengan efisiensi tersebut maka produktivitas perusahaan pun akan dapat dicapai.

Beberapa penelitian sistem informasi sumber daya manusia telah dilakukan untuk berbagai bidang perusahaan. Sistem informasi sumber daya manusia untuk bidang usaha jasa seperti bidang teknologi terutama untuk pengurusan cuti dan klaim [9] dan jenis usaha pengangkutan [10].

Konfeksi Oidokids merupakan konfeksi yang menghasilkan brand baju muslim anak yang berlokasi di Bandung dan memiliki karyawan kurang lebih 50 orang. Absensi di konfeksi Oidokids terbagi menjadi absensi harian dan absensi mingguan/setor. Absensi harian yaitu absensi yang dihitung dari hari kerja dan terdiri dari admin kantor, admin pemasaran, editor dan controlling. Sedangkan Absensi mingguan/setor yaitu absensi yang dihitung dari jumlah setoran yang didapat dan terdiri dari bagian produksi.

Aktivitas pengelolaan karyawan di konfeksi Oidokids mulai dari penerimaan karyawan, pelatihan karyawan, absensi karyawan dan penggajian karyawan masih belum terkelola dengan baik karena masih menggunakan pencatatan manual saja dan belum memanfaatkan suatu sistem informasi sumber daya manusia (SDM). Hal tersebut menimbulkan beberapa permasalahan seperti data-data karyawan tidak terarsipkan dengan baik dan mudah hilang. Selain itu perhitungan penggajian pun lebih lama dan rentan terhadap kesalahan karena dihitung secara manual. Dari permasalahan-permasalahan tersebut konfeksi Oidokids membutuhkan sistem informasi sumber daya manusia (SDM) untuk mengelola data karyawan . Pengelolaan sumber daya manusia (SDM) di Konfeksi Oidokids juga memiliki peranan penting terhadap perkembangan karyawan agar nantinya bisa terarah sesuai tujuan, hal ini dapat dilakukan dengan cara memperhatikan setiap sumber daya manusia yang diolah untuk melakukan tanggung jawabnya atau proses pencapaian tujuan perusahaan.

Dengan adanya sistem informasi sumber daya manusia ini maka pengelolaan data penerimaan , pelatihan, absensi dan penggajian karyawan maupun data karyawan dapat dilakukan dengan lebih mudah, cepat, dan akurat. Selain itu proses pembuatan laporan pun akan lebih mudah dan cepat.

\section{METODE PENELITIAN}

Metode penelitian yang digunakan dalam penelitian ini yaitu metode pengembangan perangkat lunak dengan model waterfall menurut Pressman [11] yang dapat dilihat pada gambar 1 .

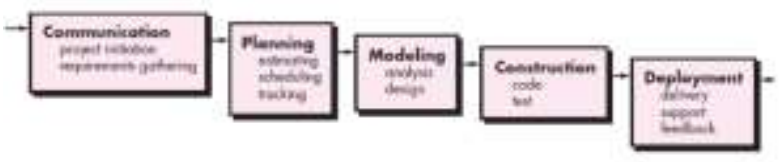

Gambar 1. Model Waterfall Menurut Pressman

a. Communication

Pada tahap ini dilakukan komunikasi dengan pihak konfeksi Oidokids terutama dengan bagian yang mengelola karyawan dan pimpinan untuk mengetahui permasalahan yang terjadi dan untuk mendapatkan informasi yang dibutuhkan dalam membuat sistem informasi sumber daya manusia.

b. Planning

Pada tahap ini diperkirakan hal-hal yang dibutuhkan dan sumber daya yang tersedia untuk membuat sistem informasi SDM di konfeksi Oidokids. Selain itu dilakukan penjadwalan mulai dari tahap komunikasi hingga konstruksi.

c. Modeling

Pada tahap ini dilakukan pemodelan untuk sistem yang akan dibangun dengan menggunakan unified modeling language (UML). Entity Relationship diagram dibuat untuk memodelkan data yang secara fisik yang nantinya akan dirancang dalam sebuah tabel database. Perancangan antarmuka dari sistem juga dibuat dalam tahap ini.

d. Construction

Sistem informasi ini dibangun dengan menggunakan bahasa permrograman PHP serta codeigniter sebagai framework. Untuk pengelolaan database menggunakan MySQL sebagai database servernya

e. Deployment

Sistem informasi ini akan digunakan untuk mengelola sumber daya manusia di konfeksi Oidokids. 


\section{HASIL PENELITIAN}

\subsection{Analisis Sistem Berjalan}

Pada saat ini aktivitas pengelolaan karyawan di konfeksi Oidokids yaitu mulai dari penerimaan, pelatihan, absensi dan penggajian belum menggunakan suatu sistem terkomputerisasi. Gambar 2 merupakan swimlane diagram penerimaan karyawan yang sedang berjalan di konfeksi Oidokids.

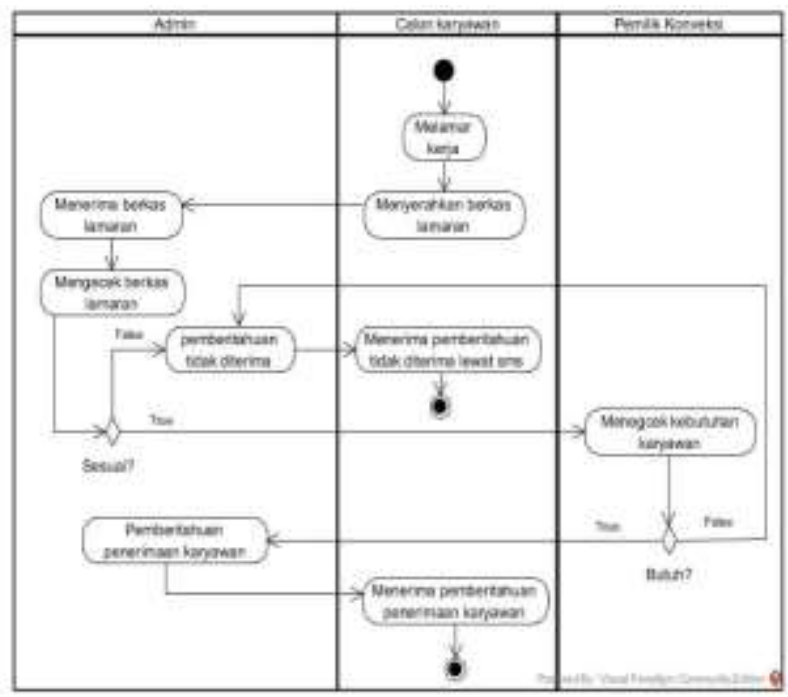

Gambar 2. Swimlane Diagram Penerimaan Karyawan yang sedang Berjalan

Aktivitas penerimaan karyawan pada konfeksi Oidokids dimulai dari calon karywan yang mengajukan lamaran kepada perusahaan. Perusahaan akan mengecek kelengkapan berkas lamaran. Apabila berkas lengkap maka akan dicek kebutuhan karyawan. Jika dibutuhkan maka akan diinformasikan kepada pelamar mengenai penerimaan karyawan dan selanjutnya calon karyawan akan ditraining sesuai dengan kebutuhan.

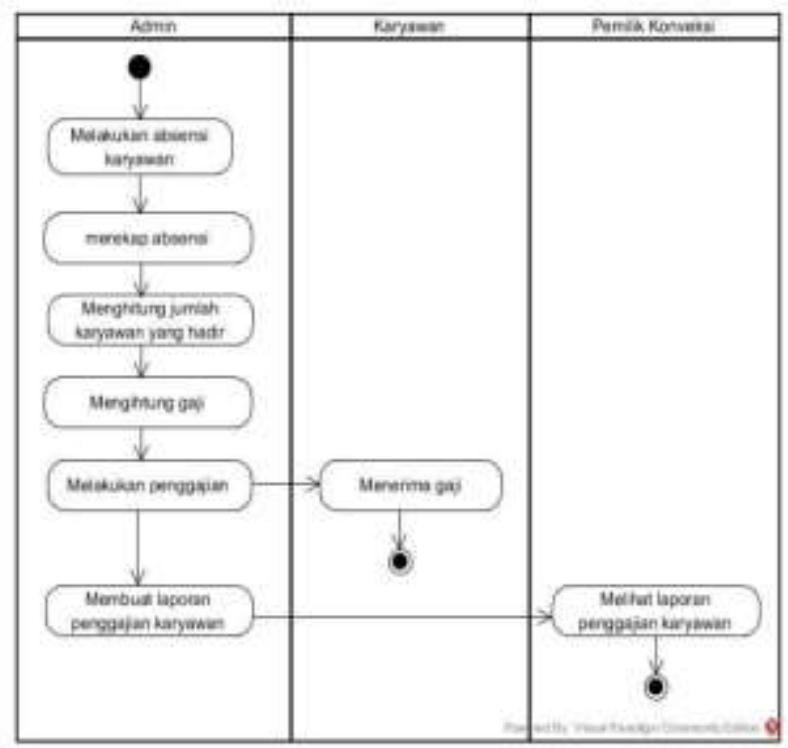

Gambar 3. Swimlane Diagram Penggajian Bulanan yang Sedang Berjalan
Gambar 3 merupakan swimlane diagram penggajian bulanan untuk karyawan konfeksi Oidokids yang dihitung dari jumlah kehadirannya. Jumlah kehadiran dihitung pada setiap akhir bulan yang kemudian dikalikan dengan nilai upah per kehadiran .

\subsection{Pemodelan Sistem}

Untuk memodelkan sistem informasi sumber daya manusia yang akan dibangun di konfeksi Oidokids, dalam penelitian ini menggunakan beberapa diagram UML yaitu use case diagram, swimlane diagram, sequence diagram, dan class diagram.

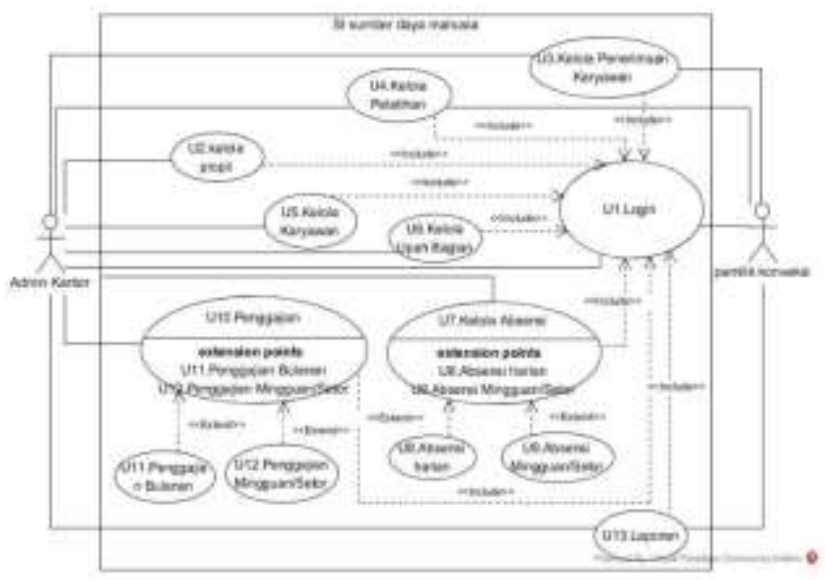

Gambar 4. Use Case Diagram Sistem Informasi SDM

Use case diagram sistem informasi SDM di konfeksi Oidokids ditunjukkan pada gambar 4. Pada use case ini digambarkan interaksi aktor yaitu admin dan pemilik dengan sistem yang akan dibuat. Terdapat 13 use case dimulai dari kedua aktor membuka login hingga pembuatan laporan. Terdapat beberapa fungsi utama SDM pada use case ini yaitu penerimaan karyawan, pelatihan, absensi, dan penggajian.

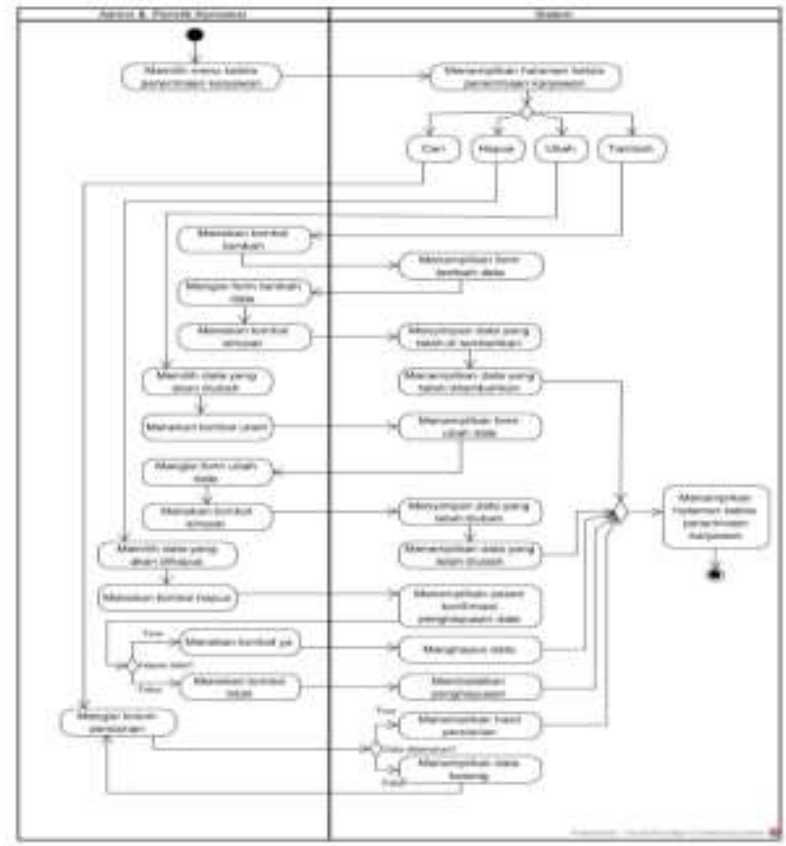

Gambar 5. Swimlane Diagram Penerimaan Karyawan 
Gambar 5 menunjukkan swimlane diagram penerimaan karyawan. Terdapat beberapa aktivitas yaitu tambah, ubah, hapus dan pencarian data.

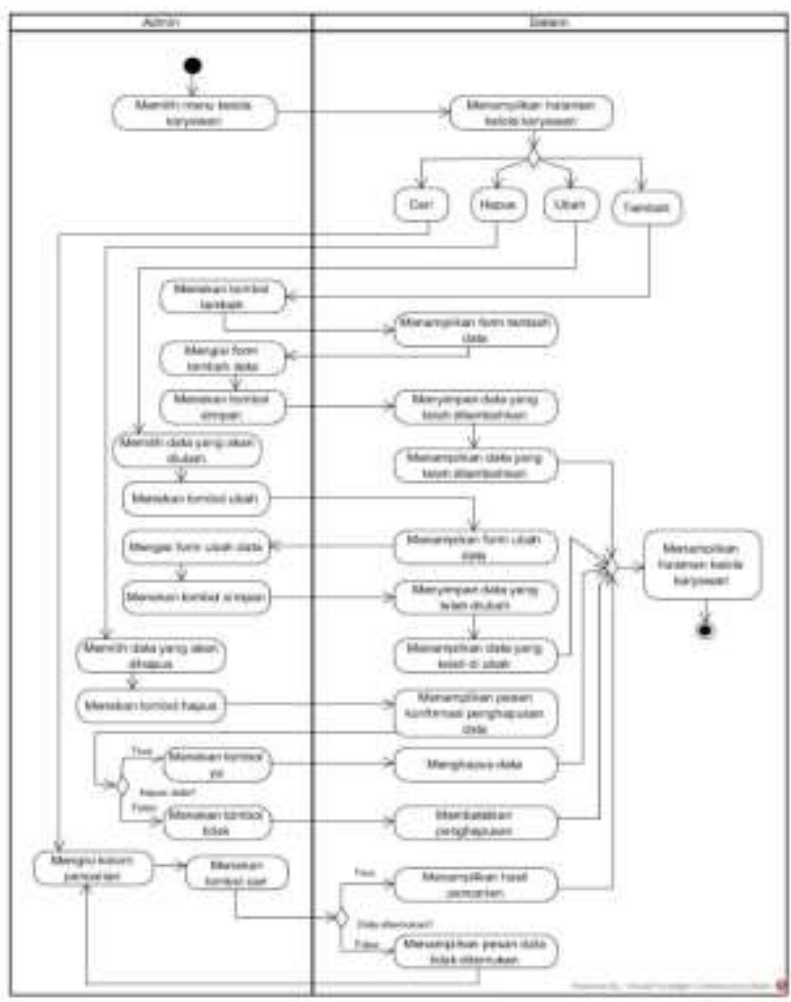

Gambar 6. Swimlane Diagram Pengelolaan Karyawan

Gambar 6 menunjukkan swimlane diagram pengelolaan karyawan yaitu halaman yang akan digunakan untuk mengelola data-data karyawan di konfeksi Oidokids.

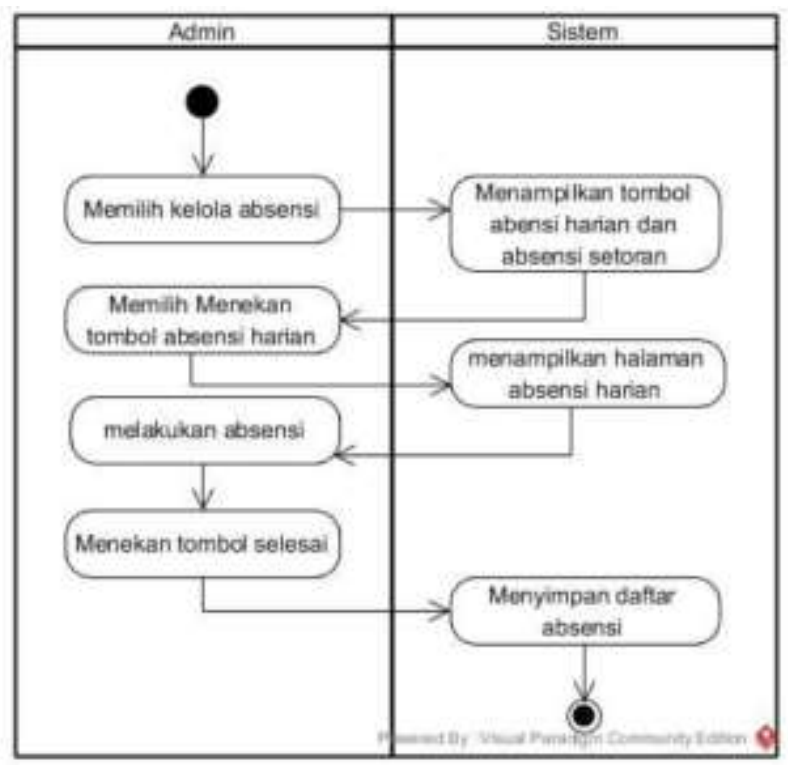

Gambar 7. Swimlane Diagram Absensi Harian

Gambar 7 menunjukkan swimlane diagram absensi harian. Absensi harian digunakan untuk karyawan dengan sistem penggajian bulanan.

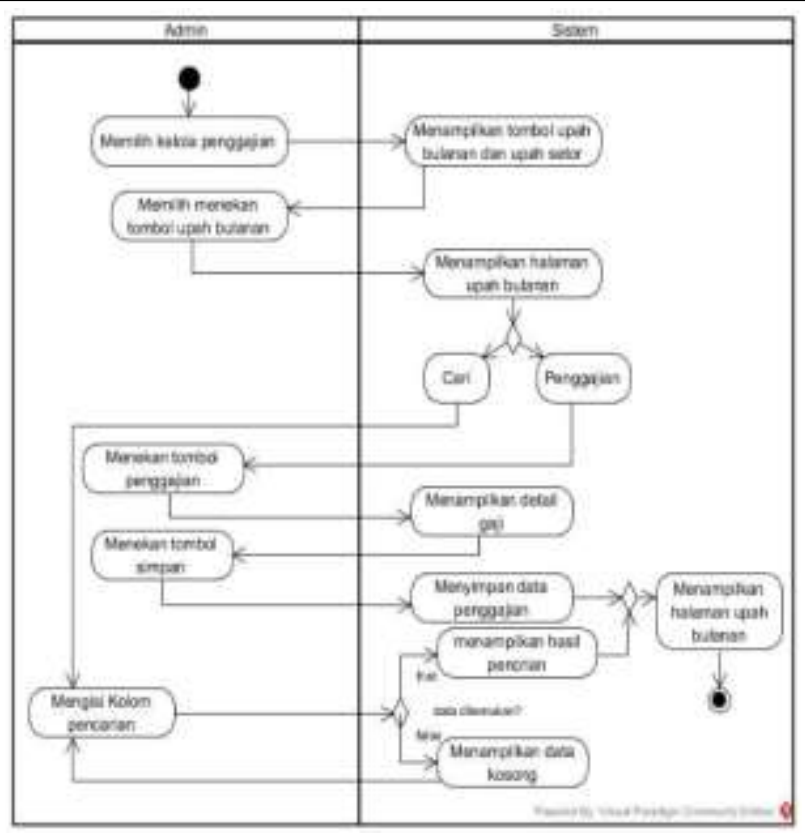

Gambar 8. Swimlane Diagram Kelola Penggajian Bulanan

Gambar 8 menunjukkan swimlane diagram kelola penggajian bulanan dimana besarnya gaji yang diterima berasal dari jumlah absensi dikalikan dengan standar upah.

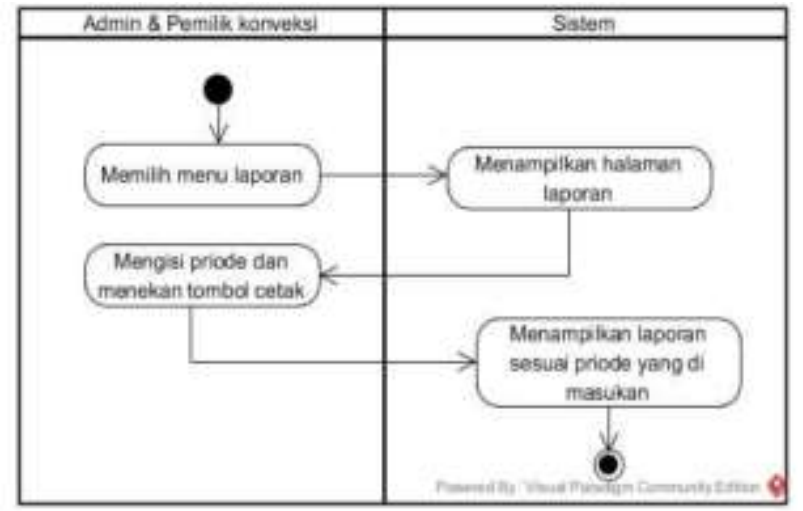

Gambar 9. Swimlane Diagram Kelola Laporan

Gambar 9 menunjukkan swimlane diagram kelola laporan. Laporan dibutuhkan oleh pemilik konfeksi. Untuk memilih laporan yang dibutuhkan dilakukan filter terhadap periode yang dibutuhkan. 


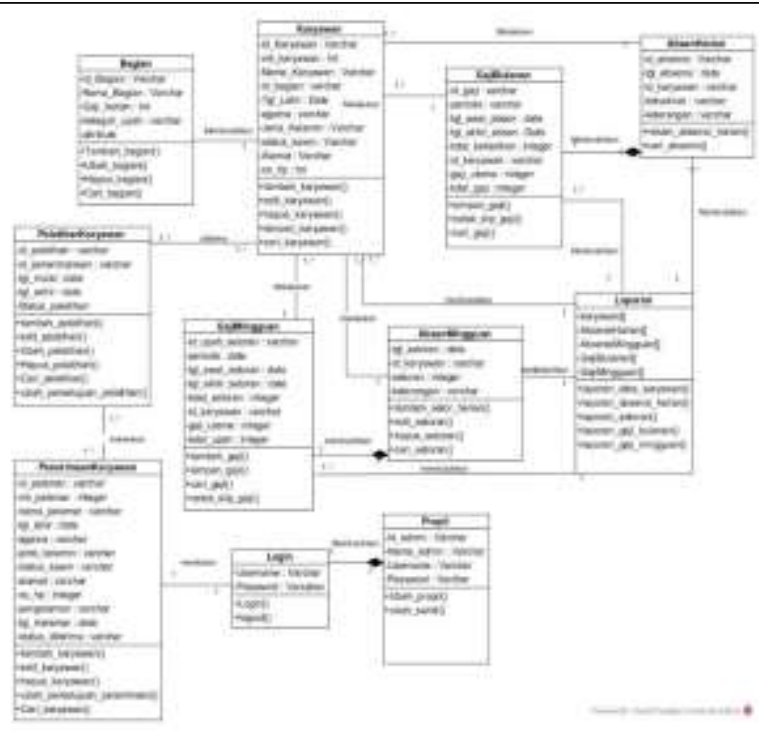

Gambar 10. Class Diagram Sistem Informasi SDM

Pada gambar 10 yaitu class diagram, terdapat 11 kelas yang digunakan dalam sistem informasi ini yaitu class login, profil, karyawan, upah bagian, absen harian, absensi mingguan, gaji bulanan, gaji mingguan pelatihan karyawan, penerimaan karyawan dan laporan.

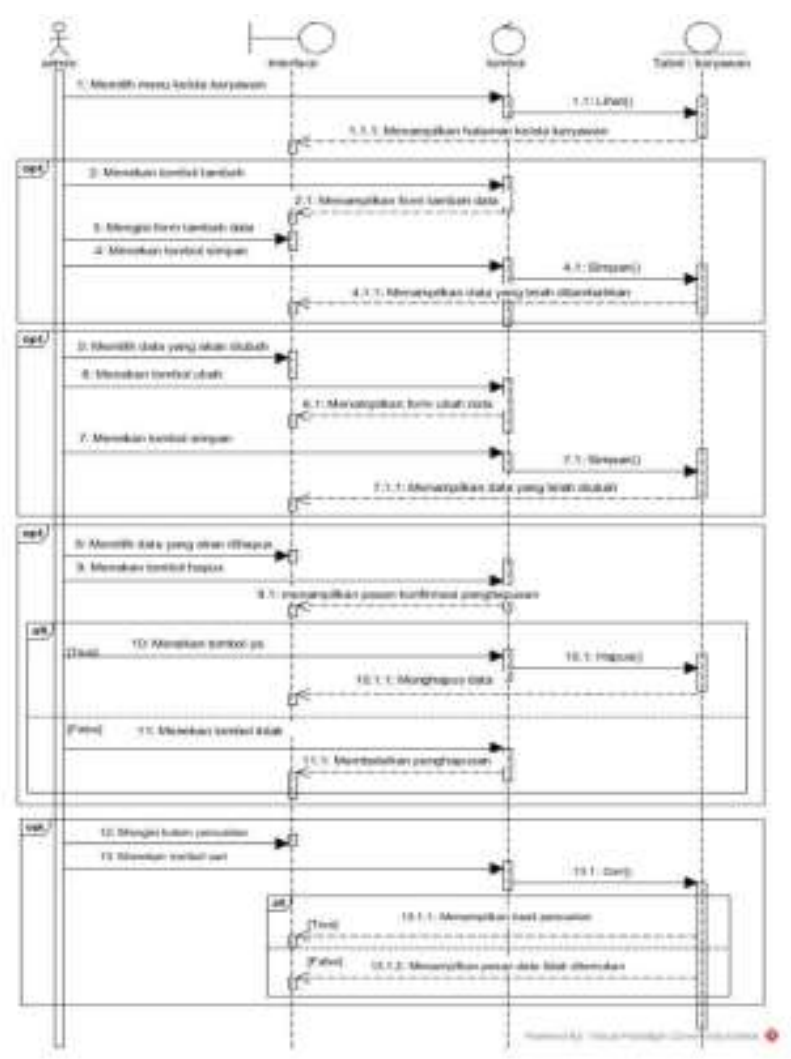

Gambar 11. Sequence Diagram Kelola Karyawan

Pada sequence diagram kelola karyawan yang ditunjukkan di gambar 11, menjelaskan bagaimana urutan operasi-operasi yang terdapat pada halaman pengelolaan karyawan dilakukan antara admin dan objek-objek yang berhubungan.

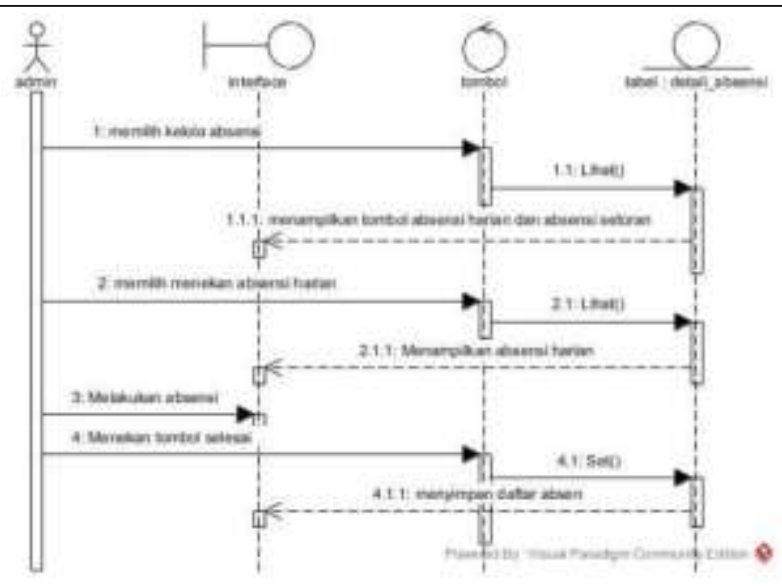

Gambar 12. Sequence Diagram Kelola Absensi Harian

Gambar 12 menunjukkan sequence diagram kelola absensi harian dimana terlihat urutan operasi-operasi yang dilakukan admin mulai memilih menu kelola absensi hingga penyimpanan data.

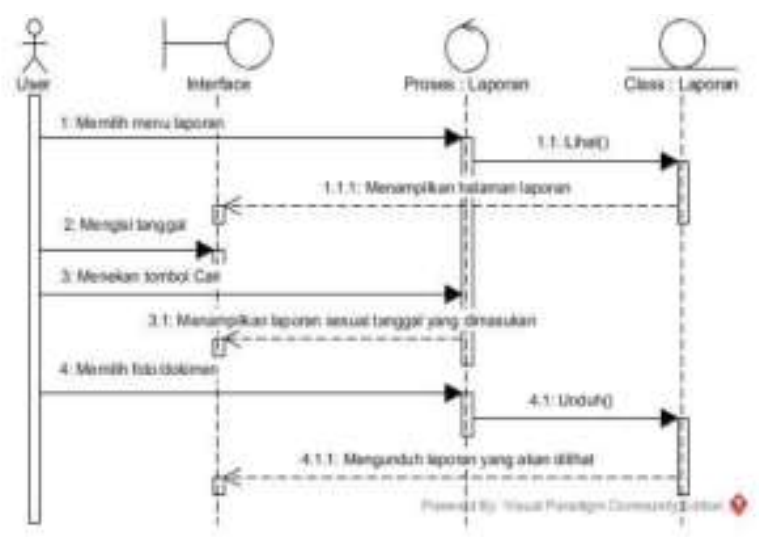

Gambar 13. Sequence Diagram Kelola Laporan

Gambar 13 menunjukkan sequence diagram kelola laporan dimana pengguna yaitu aktor admin dan pemilik memulai dengan memilih menu laporan dan kemudian ditampilkan respon dari sistem. Selajutnya pengguna memfilter laporan dengan tanggal dan akan direspon oleh sistem dengan menampilkan laporan yang dipilih. Terakhir laporan dapat diunduh oleh pengguna.

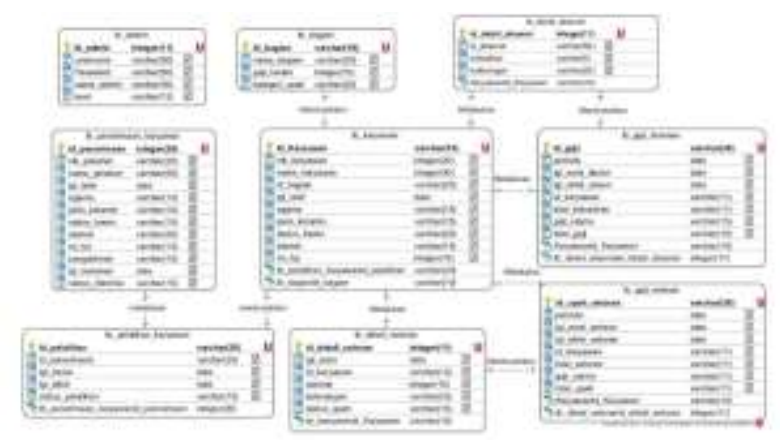

Gambar 14. Entitiy Relationship Diagram

Gambar 14 menunjukkan ERD dari sistem informasi SDM yang akan dibangun. Terdapat sembilan entitas yang saling berhubungan. Hubungan tersebut dapat dilihat dari garis relasi pada entitas. 


\section{PEMBAHASAN}

Hasil dari setiap perancangan diimplementasikan menjadi halaman-halaman dan menu-menu sesuai dengan rancangan struktur menu maupun rancangan antarmuka sistem informasi HRD konfeksi Oidokids. Berikut ini beberapa hasil implementasi dalam bentuk antarmuka yang terdapat dalam sistem yang dibuat.

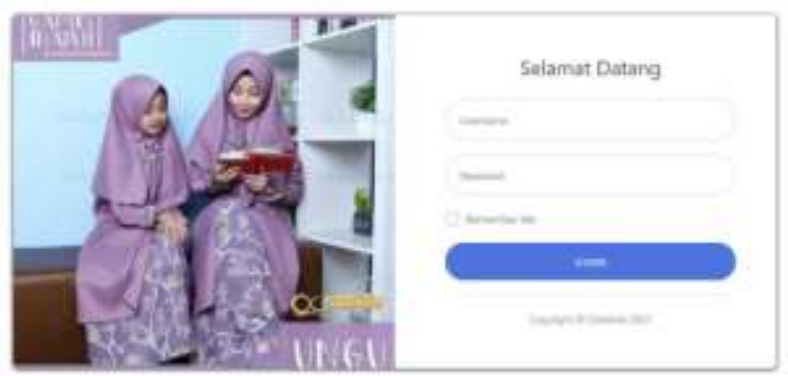

Gambar 15. Halaman Login

Halaman login ditunjukkan pada gambar 15. Halaman ini merupakan halaman awal yang harus diisi oleh pengguna yaitu admin dan pemilik sebelum mengakses sistem informasi SDM ini.

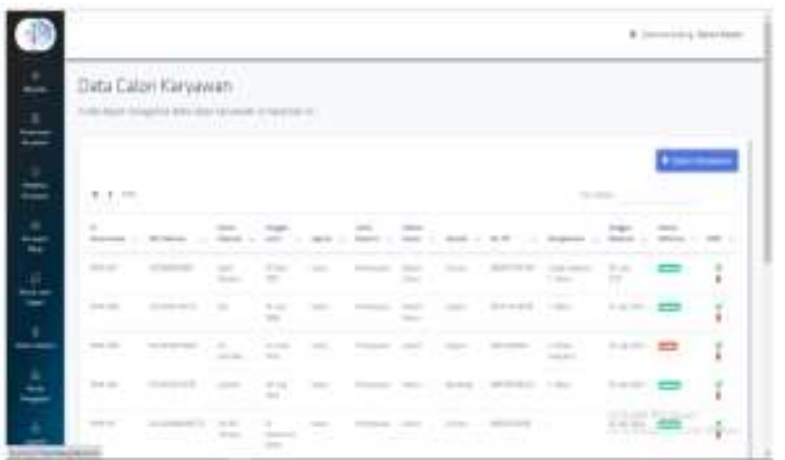

Gambar 16. Halaman Penerimaan Karyawan

Pada gambar 16 adalah halaman penerimaan karyawan, digunakan untuk mengelola data para pelamar di konfeksi Oidokids.

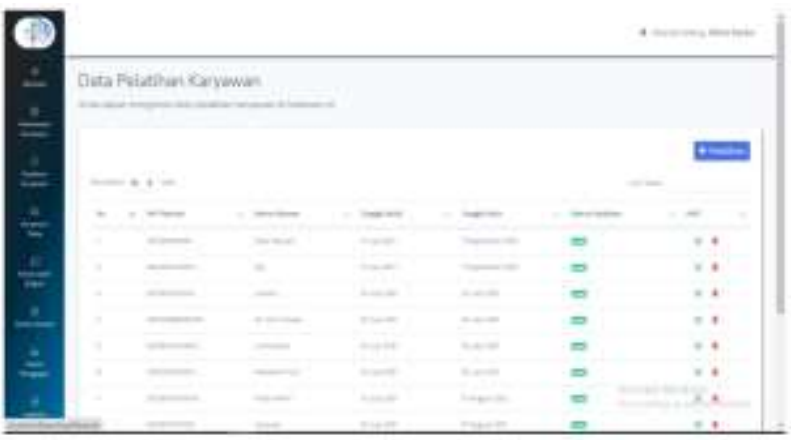

Gambar 17. Halaman Pelatihan Karyawan

Gambar 17 merupakan halaman pelatihan karyawan. Halaman ini digunakan untuk mengelola data pelatihan calon karyawan yang telah diterima. Terdapat tanggal mulai dan berakhirnya pelatihan serta status lulus atau tidaknya.

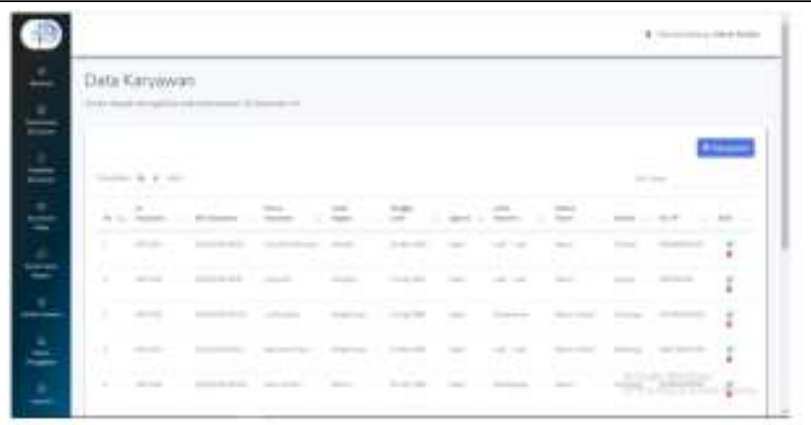

Gambar 18. Halaman Kelola Karyawan

Gambar 18 merupakan halaman pengelolaan data karyawan. Terdapat fungsi tambah, ubah, hapus, dan cari pada halaman ini. Semua data karyawan baik yang pekerja harian maupun mingguan dikelola di halaman tersebut.

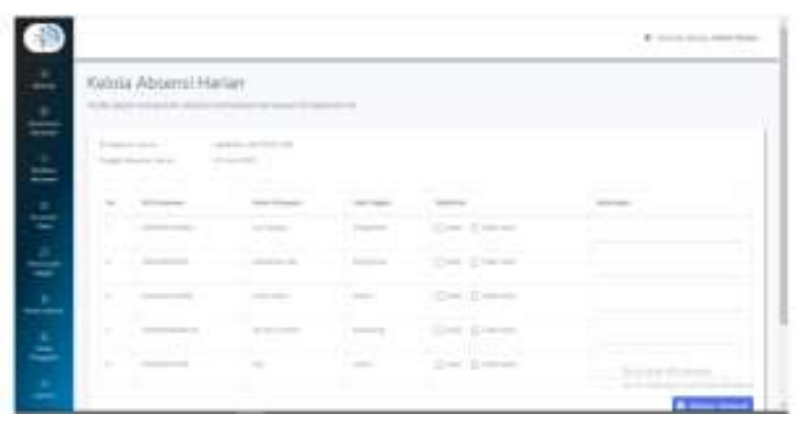

Gambar 19. Halaman Kelola Absensi Harian

Gambar 19 menunjukkan halaman kelola absensi harian. Halaman ini digunakan untuk memasukkan data absensi untuk karyawan yang memiliki jadwal kerja setiap hari. Terdapat keterangan hadir dan tidaknya karyawan.

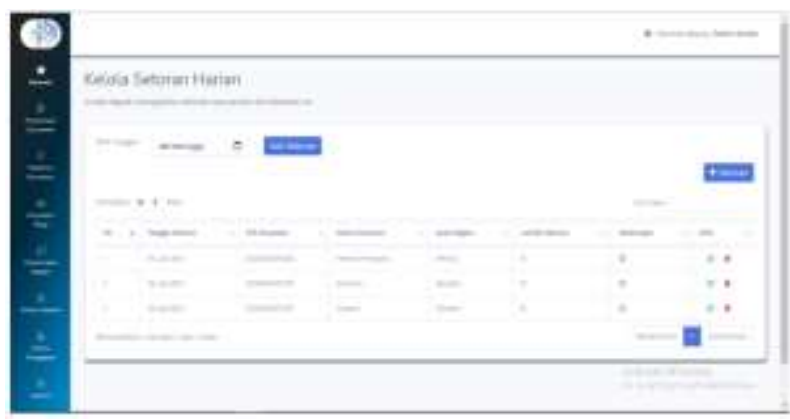

Gambar 20. Halaman Kelola Setoran

Gambar 20 merupakan halaman kelola setoran. Halaman ini digunakan untuk memasukkan data jumlah setoran produk dari beberapa bagian di konfeksi Oidokids.

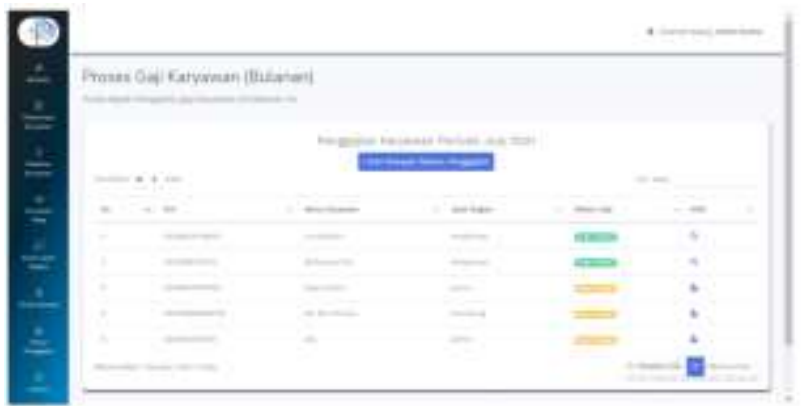

Gambar 21. Halaman Penggajian Karyawan Bulanan 
Gambar 21 merupakan halaman penggajian karyawan bulanan. Gaji yang diterima berdasarkan kehadiran harian karyawan.

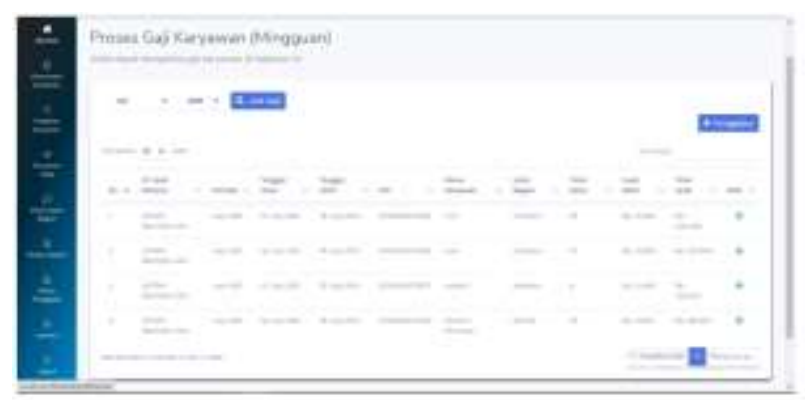

Gambar 22. Halaman Penggajian Karyawan Mingguan

Gambar 22 merupakan halaman penggajian karyawan mingguan. Gaji yang diterima berdasarkan setoran produk yang diberikan setiap minggunya.

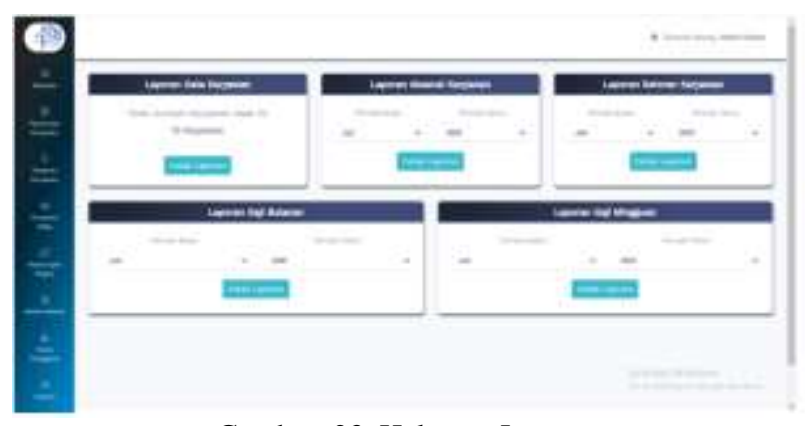

Gambar 23. Halaman Laporan

Untuk membuat laporan dapat diakses di halaman laporan. Pada halaman ini terdapat filter laporan berdasarkan periode dan pengguna dapat mencetak laporan yang ada.

\section{KESIMPULAN}

1. Pada penelitian ini telah berhasil dibangun suatu sistem informasi sumber daya manusia di konfeksi Oidokids Bandung.

2. Sistem informasi sumber daya manusia merupakan sebuah sistem yang dapat digunakan untuk mengelola penerimaan karyawan dan melakukan proses pelatihan karyawan

3. Sistem informasi sumber daya manusia ini dapat memudahkan admin dalam mengelola data karyawan.

4. Sistem informasi sumber daya manusia merupakan sebuah sistem yang dapat digunakan untuk melakukan absensi serta memudahkan admin dalam melakukan penggajian karyawan.

5. Pada sistem informasi sumber daya manusia ini juga dilengkapi dengan laporan, hal ini dapat memudahkan admin dan pemilik untuk melihat detail laporan.

\section{REFERENSI}

[1] M. Hasibuan, Manajemen Sumber Daya Manusia, Revisi. Jakarta: PT. Bumi Aksara, 2000.

[2] T. Ndraha, Pengantar Teori Pengembangan Sumber Daya Manusia. Jakarta: Rineka Cipta, 1999.

[3] G. Dessler, Manajemen Sumber Daya Manusia, Edisi 14. Jakarta: Salemba Empat, 2015.

[4] H. J. Robert, L Mathis ; John, Human Resource Management, Edisi 10. Jakarta: Salemba Empat, 2011.

[5] S. K. Boell and D. Cecez-Kecmanovic, "What is an information system?," Proc. Annu. Hawaii Int. Conf. Syst. Sci., vol. 2015-March, pp. 4959-4968, 2015, doi: 10.1109/HICSS.2015.587.

[6] R. Anggraeni, E. Y \& Irviani, Pengantar Sistem Informasi. Yogyakarta: Andi, 2017.

[7] M. H. Tigari, "Human Resource Information System: A Theoretical Perspective,” Int. J. Trend Sci. Res. Dev., vol. Volume-2, no. Issue-1, pp. 1406-1410, 2017, doi: 10.31142/ijtsrd8245.

[8] L. Suharti and P. R. Sulistyo, "The implementation of human resources information system and it 's benefit for organizations," Diponegoro Int. J. Bus., vol. 1, no. 1, pp. 1-7, 2018, doi: 10.14710/dijb.1.1.2018.1-7.

[9] N. K. Wardhani, M. Thariq, and A. Aziz, "SISTEM INFORMASI MANAJEMEN SUMBER DAYA MANUSIA BERBASIS WEB ( STUDI KASUS : PT . KLIK TEKNOLOGI INDONESIA )," vol. 15, no. 2, pp. 145-152, 2018.

[10] D. P. Sugumonrong, "DAYA MANUSIA PADA PT SUMATRA SARANA SEKAR SAKTI," $J$. ISD, vol. 3, no. 1, pp. 79-85, 2018.

[11] R. S. Pressman, Rekayasa Perangkat Lunak: Pendekatan Praktisi, Buku I. Yogyakarta: Andi, 2015. 